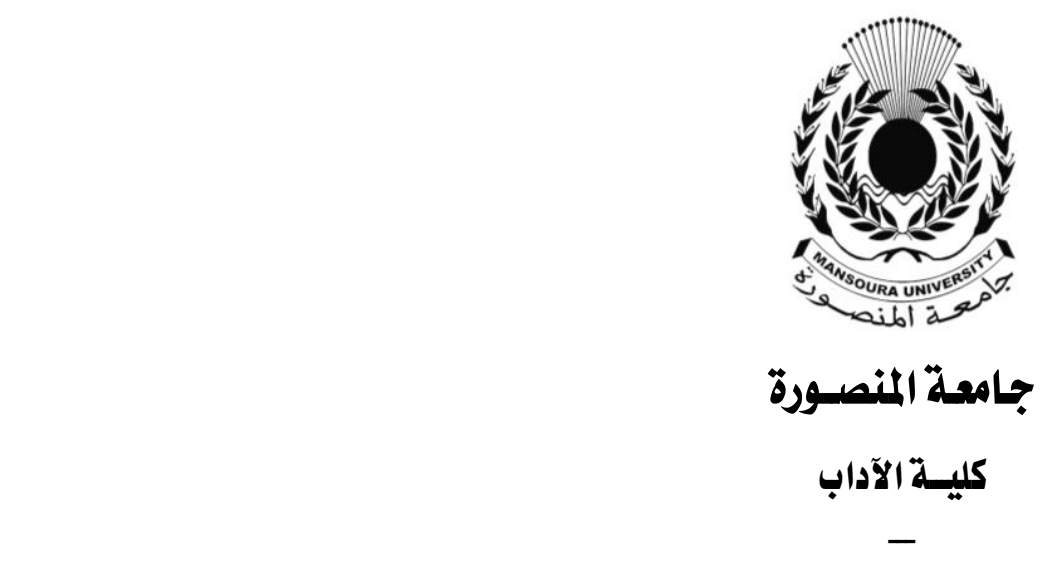

علم الإقاصد وتاريخه وتطوره

إعـــــ

محمد عبدالمزيز محمد محمد جعثر

باحث لدرجة الماجستير - قسم الفلسفة

كلية الآداب- جامعة المنصورة

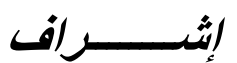

أ.د/السيلد محمد عبد الرحمن

أستاذ الفلسفة الإسلامية والتصوف

كلية الأداب - جامعة المنصورة

مجــلة كلــية الآداب - جـامعـة المنصـورة

العدد السادس والستون - r.r.r. 


\section{علم المقاصد وتاريخه وتطوره}

\section{محمد عبدالعزيز محمد محمد جعفر}

باحث لدرجة الماجستير - قسم الفلسفة

كلية الآداب - جامعة المنصورة

التكامـل المراعى في تشـريعات الإسـلام والذني

يتجاوز إطار المادة الضيق"(r).

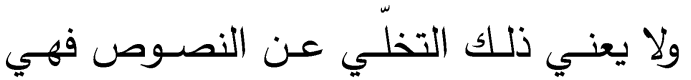

الأصل الأصيل والركن الركين، والمقاصد آلة لها لها

لفهم علل أحكامها وتتزيلها على الواقع، وهذا

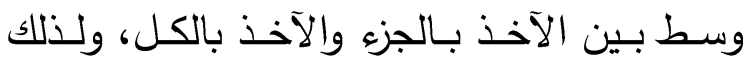

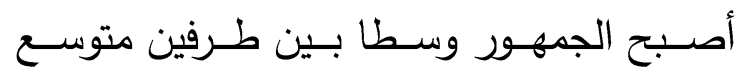

ومشدد، حيث أعملوا النصوص من كتاب وسنة لئة

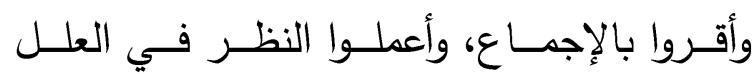

والمعاني المستتبطة من الأحكام، فكانوا وسطًا

بين طرفى نقيض، كما خص الله - جل وعلا-

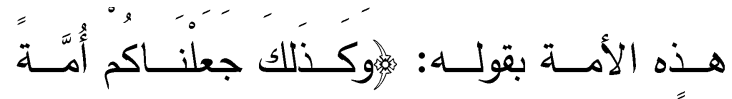

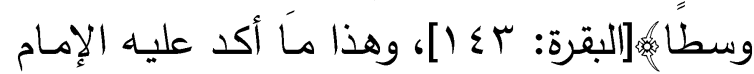

الثاطبي في موافقاته بقوله: "بماذا يعرف ما هو

مقصود للشارع مما ليس مقصودا له؟، والجواب:

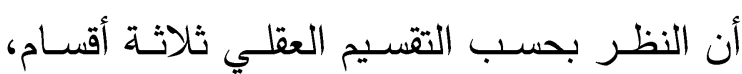

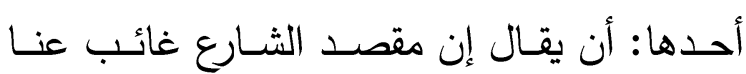

حتى يأتينا النص الذي يعرفنا به وليس ذلك إلا

بالتصريح الكلامى مجردا عن تتبع المعاني التي باتئي

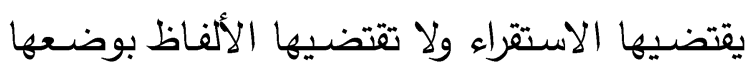

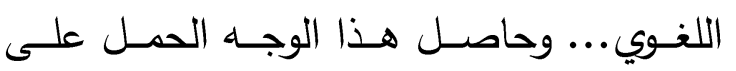

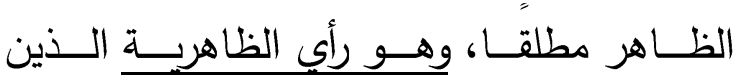

(') أحمد بـن يوسف السيد: محاسـن الإنـلام نظـرات

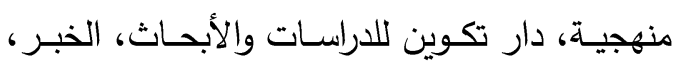

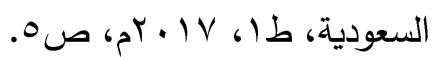

لقد كانـت المقاصــ تسـري في روح الصــابة وعقولهم، اكتسبوها من النصوص القرآنية، ومن الن

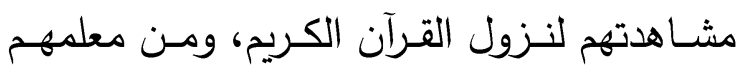

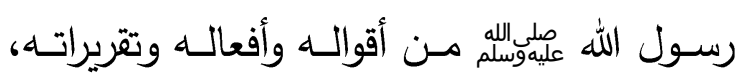
فأكسبهم ملكة يعرفون بها مقاصد الثريعة، ولم

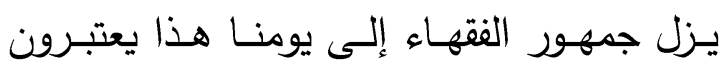
المقاصــــــي أحكـامهم وفـي فتـاويهم، وتــارة ينصون على ذلك، وتارة يعتبرونه فيما ينظرون

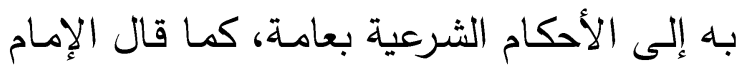

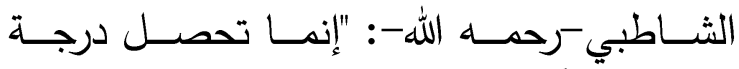
الاجتهاد لمن اتَصف بوصفين: إحداهما: فهرم مقاصد الشَريعة على كمالها، والثاني: التمكن التهن

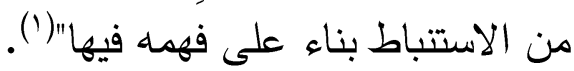

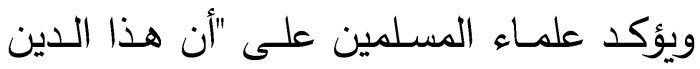
العظيم لا تفهم محاسنه ولا يتوصل إلى جمالياته

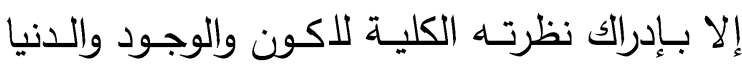

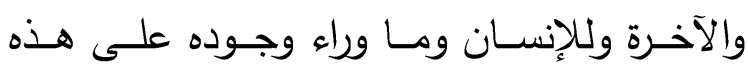

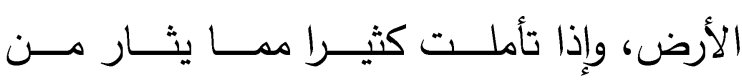

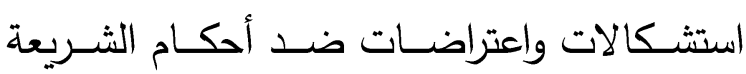
فستجد أنها منبثقة من تجزئه النظر إلى الإنسان

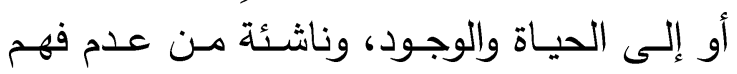

(') الثاطبي: الموافقات، جه، تحقق مشهور آل سلمان،

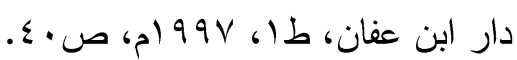


طريقة الجمهور ، فتصبح المقاصد معايير الجمال والكمال فيى تتاسق الشريعة بأحكامها الكلية مـع أحكامها الجزئية.

\section{أولاً: تعريف المقاصد الشرعية:}

عـرف الثـيخ الطـاهر بـن عاشـور المقاصـــ الشرعية بقوله: "هي المعاني والحكم، الملحوظة للشـارع في جميـع أحـوال التشـريع أو معظمهـا، بحيـث لا تخـتص ملاحظتها بـالكون في نـوع خـاص مـن أحكام الشـريعة....، فيدخل في هـذا لهاع أوصـاف الثربعة وغايتها العامـة، والمعاني التي هي لـي لا يخلو التشريع عن ملاحظتها، ويدخل في هذا أيضـا معان من الحكم ليست ملحوظة في سائر أنواع الأحكام، ولكنهاً ملحوظة في أنواع كثيرة"(ع). وعرفهــا الـدكتور تحمد اليـوبي بقولـهـ: "هـــي المصـالح التي تهدف الثريعة إلى تحصيلها في جملة الأحكام وتفاصيلها"(*)، وعليه فالمقاصد هي المعـاني والحكم الكليـة والجزئيـة التي مـن أجلها شرع الله الأحكا

\section{ثانياً : علم المقاصد عبر العصور:}

علم المقاصـــ كغيـره مـن العــوم، لـم يظهـر بالصورة التي هو عليها الآن دفعة واحدة، بل مر بمراحل متعددة، فقد نشأ هذا العلم منذ أن كانت أصسوله وقواعده منثورة في الكتاب والسنة وأقوال

(") ) ابـن عاشـور : مقاصــ الثـريعة الإنــلامية، طبعــة

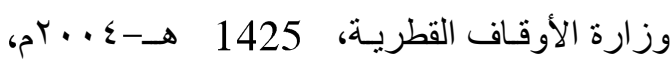

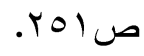

( ) محمد سـعد اليـوبي: ضـوابط إعمـال مقاصــ الثـريعة،

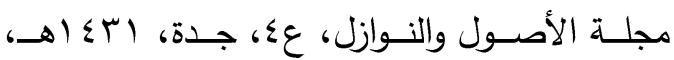

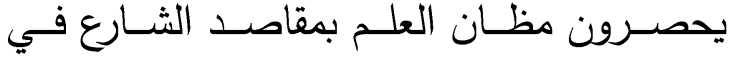
الظواهر والنصوص، والثاني: في الطرف الآخر من هذا، إلا أنه ضربان، الأول: دعوى أن مقصد ولي الشـارع ليس في هذه الظواهر ولا ما يفهم منها، وإنما المقصود أمر آخر وراءه، ويطرد ذلك في جميع الثريعة حتى لا يبقى في ظاهرها متمسك تعرف منـه مقاصد الشـارع، وهذا رأي كل قاصد لإبطـال الشـريعة وهم الباطنيـة، والضـرب الثاني: بأن يقال إن مقصود الشارع الالتفات إلى معاني

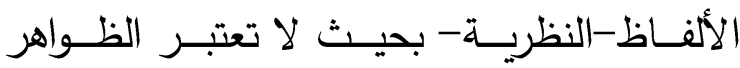
والنصـوص إلا بهـا على الإطـلاق، فـإن خـالف

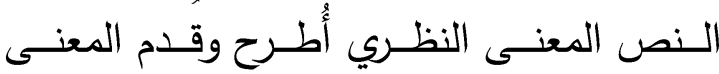
النظـري، وهـو إمـا بنـاء على وجـوب مراعـاة

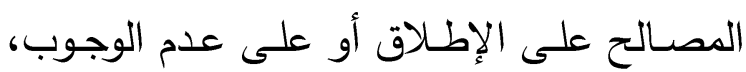
لكن مـع تحكيم المعنى جدا حتى تكون الألفاظ

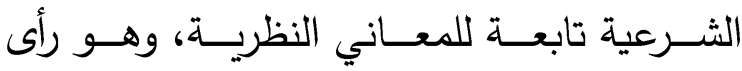
المتعدقـين فـي القيـاس، المقــدمين لــهـ علــى النصوص وهذا في طرف آخر من القسم الأول، والثالث: أن يقال باعتبار الأمـرين جميعا، على

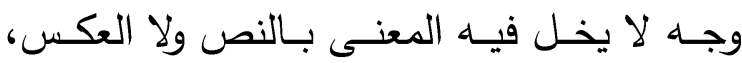
لتجري الشريعة على نظام واحد لا اختلاف فيه

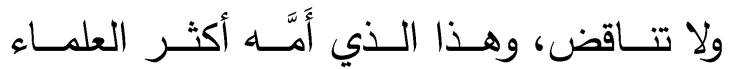
الراسـخين، فعليـه الاعتمـاد في الضــابط الـذي يعرف بـه مقصد الثرع(ז)، لهذا صسار المصنفون والمؤلفون في هذا الزمن بـين هذه الاتجاهـات الثلاثتة في الأحكام الفقهية بعامـة، وفي موضـوع

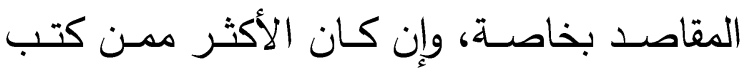
على اعتبار الآثار واعتبار المقاصـد التي هي

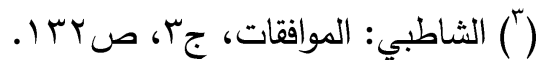




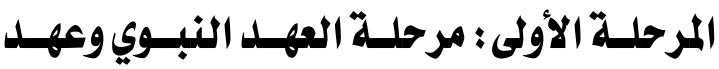

الصحابة والتابعيين : الصنائ

(1) (قتران مقاصد الثريعة بنصوص الكتاب

العزيز:

القرآن الكريم هو أسـاس الثـريعة ومصدرها

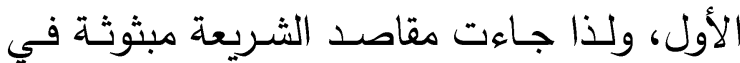

كثير من نصوصه وآياته، وذلك مثل قوله تعالى:

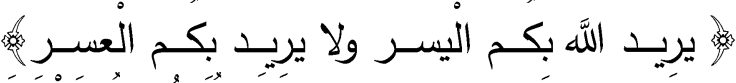

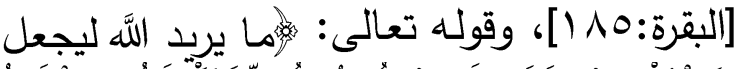

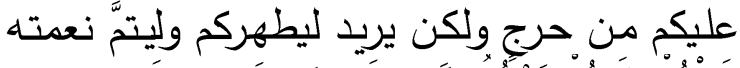

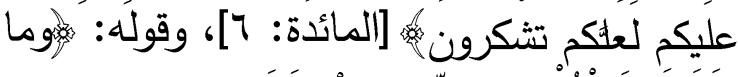

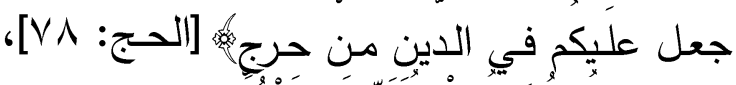

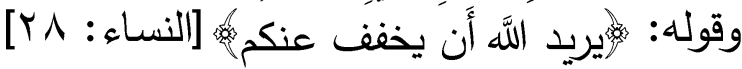
(r) وغيرها من الآيات القَرَآنية.

اقتران مقاصد الثريعة بنصوص الائنة

\section{الثريفة:}

السنة المطهرة هي المصدر الثاني للشريعة،

وهي المبينة لكثير من نصوص الكتاب العزيز، ولذا جاءت مقاصد الشريعة في كثير من أقوال

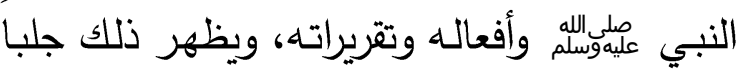
في مثل قوله- عليه الصـلاة والسلام: (إن الدين يسر )(^)، وقـال: (لا ضــرر ولا ضـرار) (9) وغيره

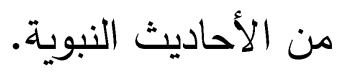

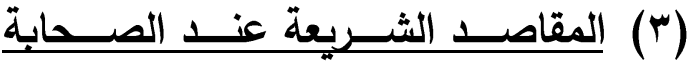

والتابعين:

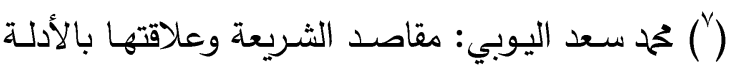

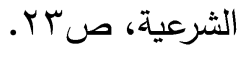

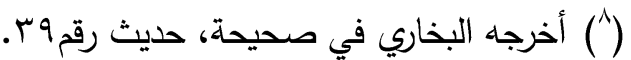

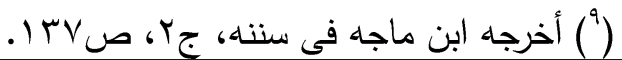

الصحابة وعبارات علماء الأمة، ثم كان بعد ذلك

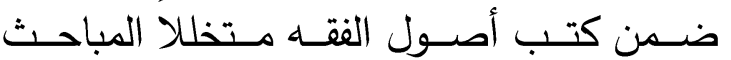
الأصولية، ثم تطور عبر العصور والأزمان إلى

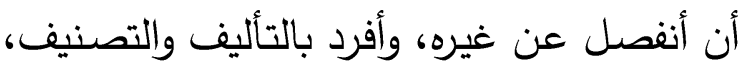
حتى وصدل إلى ما صار إليه الآن، فصار علما مستقلا عن غيره، له مؤلفاته وأصوله وقواعده. قال العلامة القرطبي في تقفيره: "ولا خـلاف بين العقلاء أن شرائع الأنبياء قصد بها مصالح

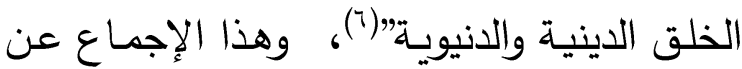
الأئعـة وسائر العلماء المعتبرين، قديم يرجع إلى لى الصحابة رضوان الله عليهم، وهو ما حققه وصرح به عدد من العلماء المحققين. وإن ما نذكره في هذه المراحل إنما هو انتقائي على سبيل المثال لا الحصر ، وذلك للاختصـار والتركيز على أعظمهم تأثيرا في مجرى تطور هذا العلم، وإلا لو دققنا البحث لوجدنا أن جل علماء

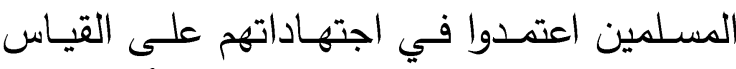

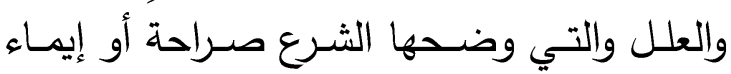
وذلك لأنها من أصل الدين والذي حصل عليها

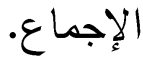
ولمعرفة نثأة وتطور علم المقاصد نسير في هذه الدراسـة على تقسيم المراحل التاريخية التي مـر بها علم المقاصد إلى ست مراحل - ولقد

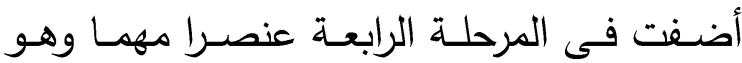
الفترة مابين الإمام الثاطبى والثيخ ابن عاشور وهذه المراحل على النحو التالي:

(") القرطبي: الجامع لأحكام القرآن (تقسير القرطبي)،

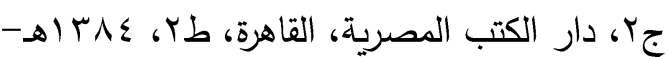
.7\& 1975 


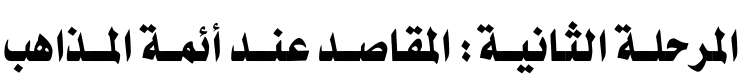

وأصسول الـدين والمتكلمين إلى مـا قبـل تثيزهـا في

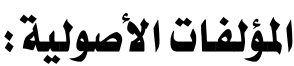

\section{(1) المقاصد عند أئمة المذاهب:}

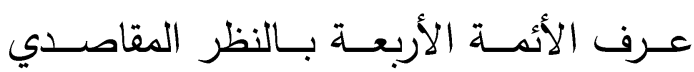

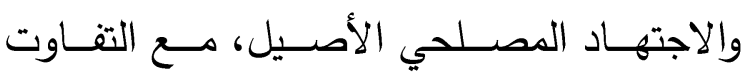

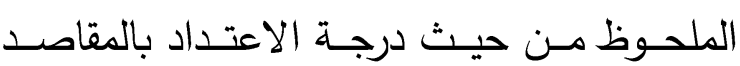

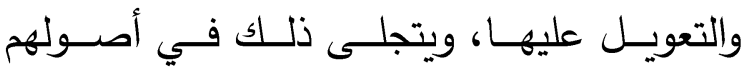
الاجتهادية ذات الصلة بالمقاصد فمنهر من بني

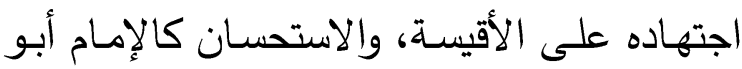
حنيفة، ومنهم من بني اجتهاده على سد الذرائع

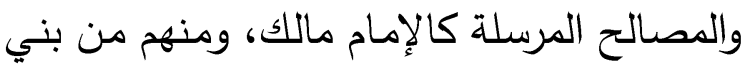

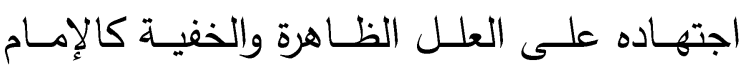

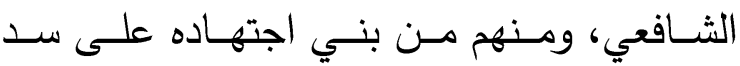

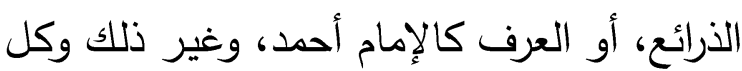
هذه القواعد أصول لعلم المقاصد (؛').

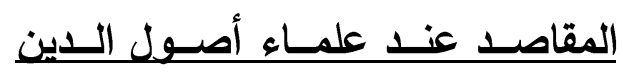
والمتكلمين:

تقد كـان لعلمـاء أصـول الدين لهم دور في

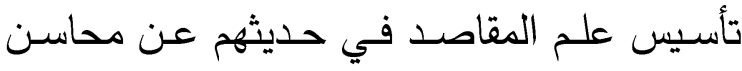
الشريعة وهو أول دافع للتأليف في هذا الفن مثل الترمذي الحكيم (ت: بسهـ)، وكذلك الفيلسوف أبو الحسن العامري (ت: إثآهـ)، فى كتابه

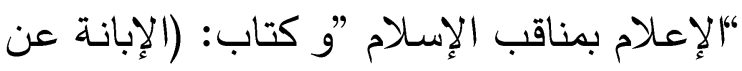

(") أ) هشام بن سعيد أزهر : مقاصد الثـريعة عند إمـام الحرمين وآثارها في التصرفات المالية (رسالة دكتوراه)،

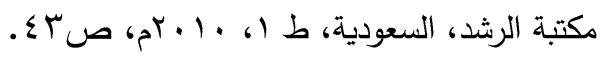

الصـابة- رضي الله عنهم- وتابعيهم الكرام هم أعلم الناس بأسرار الشريعة ومقاصدها، وذلك

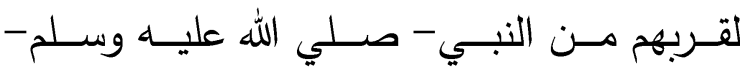

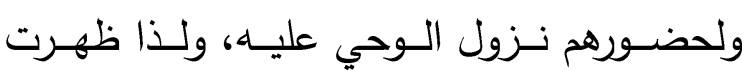
المقاصد في أقوالهم وأعمالهم، فعلى سبيل المثال

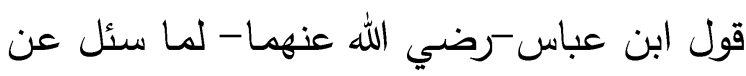

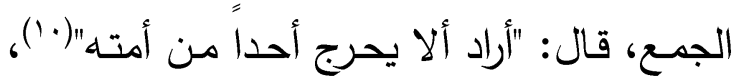

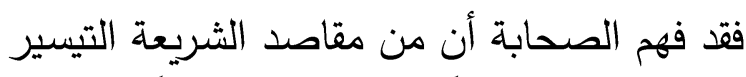

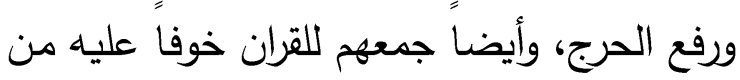

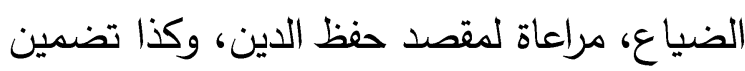

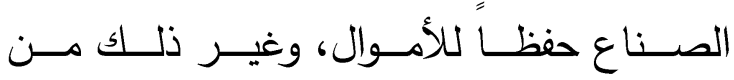

المواقف(')

"ولقد كان العمل بالمقاصد الثرعية الأصيلة

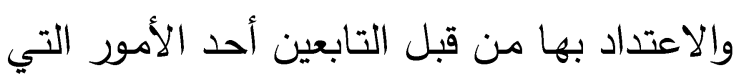

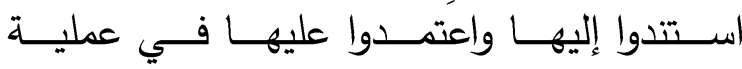

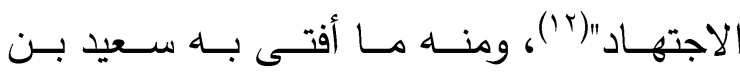

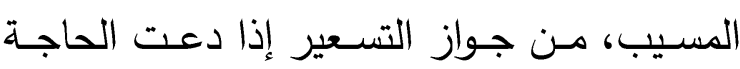

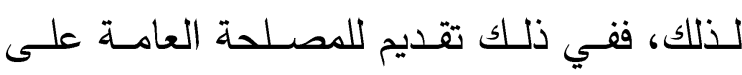

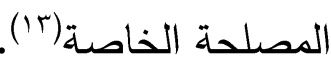
(') أخرجه مسلم في صحيحة، أحاديث رقم •0، 01 (0)، .0 0 ، 0 r (') أحمد الريسوني: محاضرات في مقاصد الثريعة،

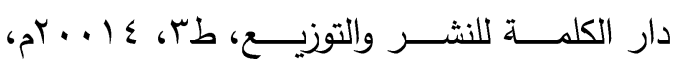

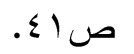

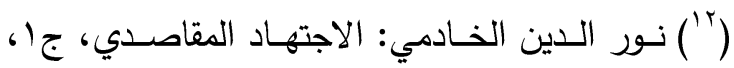

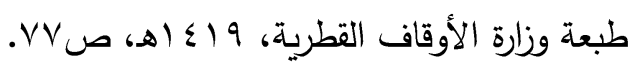

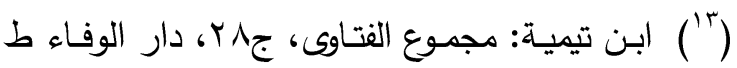

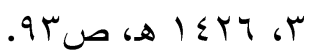


الأصـولية حيث أشـار إلى تقسيم المقاصد إلى

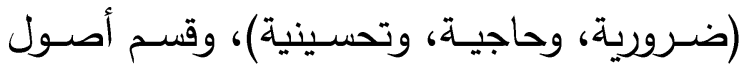
الشريعة إلى خمسة أقسام: ما يعقل معناه ويؤول

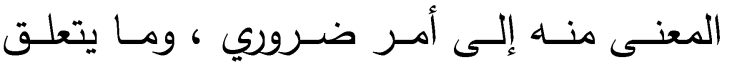

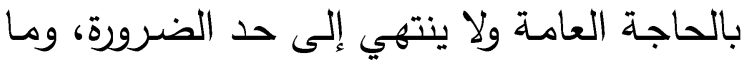
لا يتعلق بضرورة خاصـة ولا حاجة عامة، ولكن

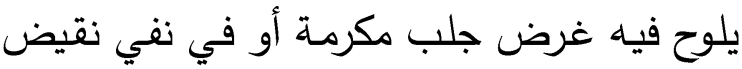

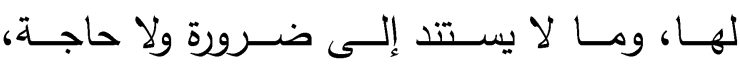
وتحصيل المقصود فيه مندوب إليه تصريحا، وما

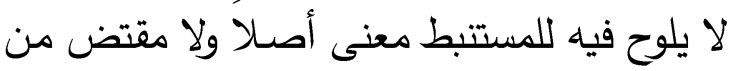

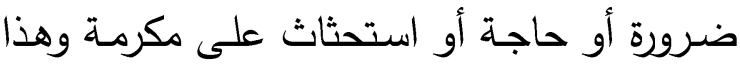
يندر تصويره جداً (')'.

\section{(Y) المقاصد عند الغزالي(ت: 0. 0هـ):}

يتجلى اهتمامه بالمقاصد حيث جعل المصلحة

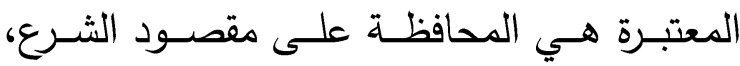
وأشار إلى الطريق الذي تعرف به المقاصد وهو

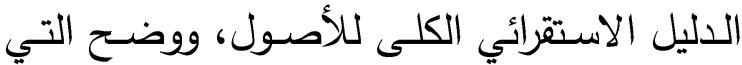

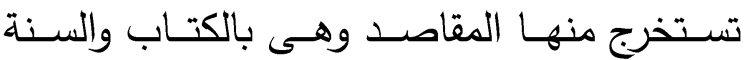
والإجماع، ثم قسم الدصلحة باعتبار قوتها في ذاتها إلى الضـروريات والحاجيـات والتحسينات، وأضاف على ما ذكره شيخه الجوينى المكمـلات

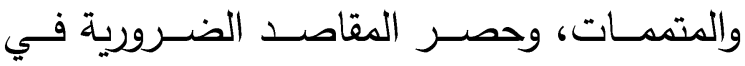
خمس وهى: حفظ الدين والنفس والعقل والنسل،

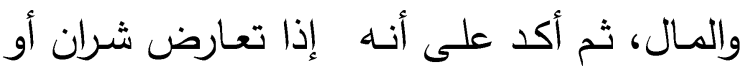

علل الديانة) (10)، وأيضا أبو عبد الله محمد بن عبد

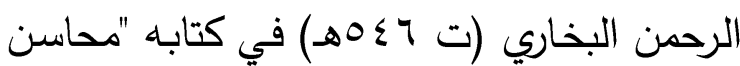
الإسلام وشرائع الإسلام".

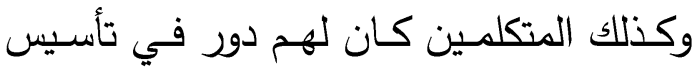
علم المقاصد في حديثهم عن العلل والمناسبة "ففي القرن الرابع ظهر لاى الفلاسفة والمتكلمين

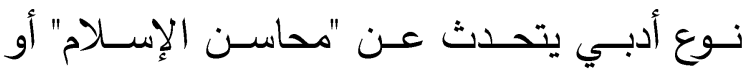

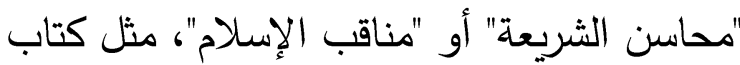

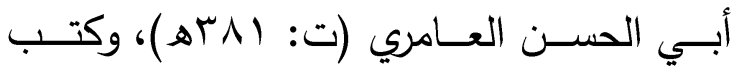

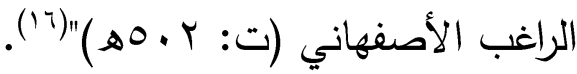

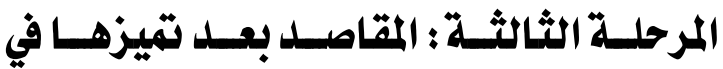 المؤلفات الأصولية من غـير أن تتميز بـالتـأليف \\ المستقل: - الم:}

حيث أن "الكتابات عن مقاصد الثريعة فيما بعد الجويني، وإلى الثاطبي، جعلت هذه المرحلة مكشـوفة ومضـاءة بدرجة جيدة بفضل الأبحاث والدراسات الكثيرة التي أنجزت حول هذه الحقبة

$$
\text { وأعلامها (v')"). }
$$

(1) المقاصــ عنــــــام إلـرمين الجـويني

$$
\text { : ه V RY:ت }
$$

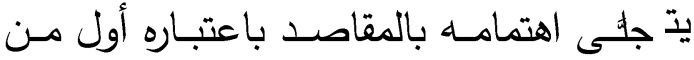
بدأت تتميز قواعد مقاصد الشريعة في كتاباته

(") الريسوني أحمد: البحث في مقاصد الثريعة نشأته وتطوره ومستقبله، raissouni.net. (') رضوان السيد: مقاصد الثريعة وممارسات الاجتهاد

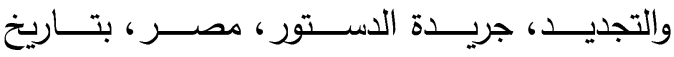

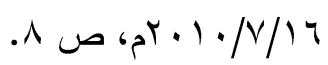
(") أحمد الريسوني: البحث في مقاصد الشريعة نثأته وتطوره ومستقبله، raissouni.net.

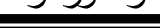


(0) المقاصد عند العز بن عبد السـلام (ت:

$:$ : 177.

يتجدى اهتمامه بالمقاصد باعتباره أول من أتى بالوسـائل وأفردها، وذكر أحكامها، والفرق بينها وبين المقاصـد، وبين حقيقـة المصـالح والأحكام المتعلقـة بهـا، وقسـمها، ورتبهـا، والتـرجيح فيمـا بينهـا، ثـم بـين حقيقـة المفاسـد وقسـها ورتبهـا، والترجيح فيما بينها، وتكلم عن مقاصد المكلفين بصـورة واضـحة وموسـعة، وتكلم عن المقاصــ الجزئية في بعض الأحكام(rr).

\section{المقاصد عند القرافي (ت: ع \اهـ).:}

يتجلى اهتمامه بالمقاصد حيث فرق بين-قاعدة المقاصد وقاعدة الوسائل وقاعدة المشقة المسقطة للعبــادة والمشـقة التـي لا تســطـها وزاد أمثلــة

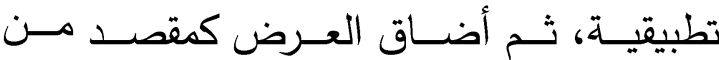

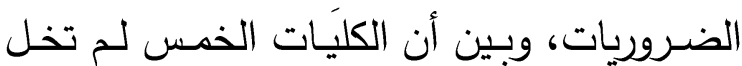
شريعة عنها، ولا يدخلها النسخ(rr). المقاصــــ عنـــــــيخ الإســلام ابـن (V) تيمية) ت :
ضـرران قصد الشـارع دفع أشد الضـررين وأعظم الثرين (19) - (19)

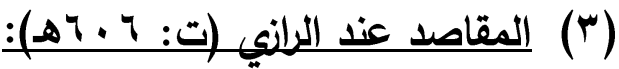
يتجلى اهتمامه بالمقاصد حيث أكد على تقسيم المقاصد إلى الضروريات والحاجيات والتحسينات في كتابـه (المحصـول)، وقسـم التحسينيات إلى قسمين: ما يقع في معارضة قاعدة معتبرة، وما لا يقـع في معارضــة قاعدة، ثم أدخل المقاصد في باب الترجيح بين الأقيسة بعد أن كانت تذكر في باب المناسبة والمصالح المرسلة فقط، وكذلك نبه على ما يعتبر من المصالح وما لا يعتبر ، وبحث مسألة التعليل بحثا مستفيضا(·r).

\section{(ع) المقاصد عند الآمدي(ت: 631هـ):}

يتجلى اهتمامسه بالمقاصد حيث أكد على إلا يتجلى اهتمامسه بالمقاصد حيث أكد على تقسيم

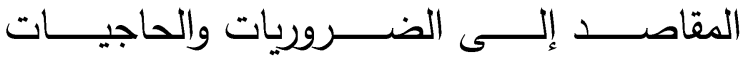
والتحسـينات، إلا أنـهـه عنـد تـرجيح الضـروريات الخمس ذكر ما يقدم منها ووسع الكلام في ذلك، فرجح الآمدي بين المقاصد نفسها('مان.

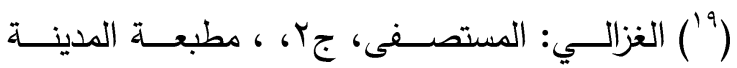

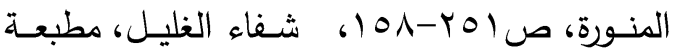

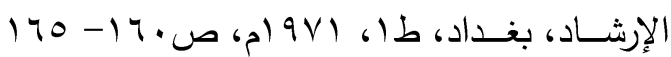

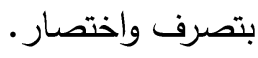

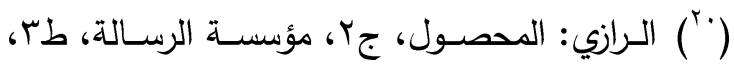
11 (') الآمدي: الإحكام في أصول الأحكام، جrا، المكتب

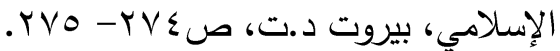


ضـرار"، وجـاء بكـلام فى شـرحه أنكر عليـه في مجميل تقديم المصلحة على النصوص والإجماع متجاوزا كل الشروط التي عبر عنها الغزالي وأكدها كل مـن الأمدي وابـن قدامـة والزركثـي وغيرهم، فقد أعرض فيها عن كل التقسيمات السابقة للمصلحة وينطلق في بنـاء نظريتهـ مـن ثقـة عاليـة بالعقل

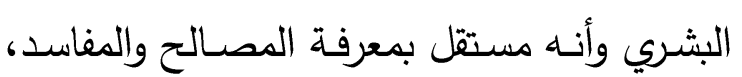
من ثم فلم يعد وجود للمصلحة المرسلة والمعتبرة والملغاة في فكر الطوفي، بل ثمـة مصلحة واحدة معتبـرة، وهــى التـي يسـتقل العقـل بإدراكهــا، والنصوص إنما تراعيها لأنه ما من آية من كتاب لئره الله عز وجل ولا حديث من السنة النبوية إلا وهي تثتمل على مصلحة أو مصالح(Tr).

\section{المرحلة الرابعة : مرحلة استقالال عليم المقاصد}

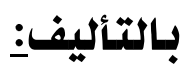

\section{(1) المقاصـــ عنـــ الثــاطبي (تـوفى ســنة}

:(AV9.

يتجلى اهتمامـه بالمقاصد حيث أسهرم إسـهاماً كبيرا في إبراز هذا العلم، فقد جمع ما تفرق عند غيره وما تراكم وتطور عند سـابقيه، لكن جمعـه

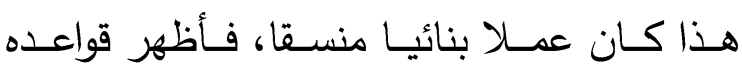
وأقسامه وأحكامه، حيث خصص لله الجزء الثاني

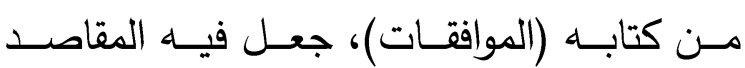

(T) الطوفي: التعيين في شرح الأربعين النووية، مؤسسة

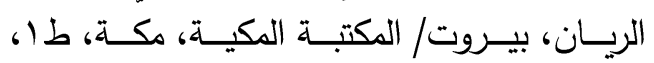

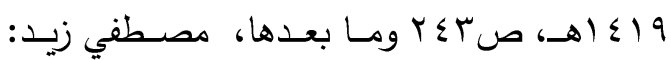
المصلحة في التشريع الإسلامي ونجم الدين الطوفي

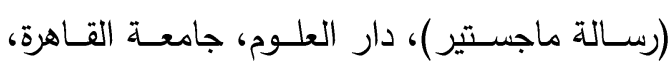

يتجلى اهتمامسه بالمقاصد حيث أكد على أن العلم بمقاصد الشريعة من خاصة الفقه في الدين، بأهما، وأكد على ضرورة معرفة المقاصد لتمييز صحيح القياس من فاسدة، ثم استدرك علي الأصسوليون حصـرهم المقاصــ الخمسـة وبين أنـه غير مسلم

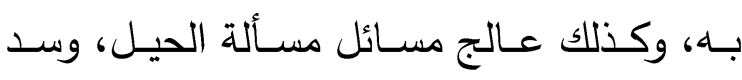

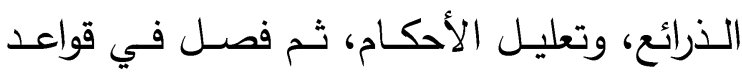
الترجيح بين المقاصد، وتوسع في بعض المقاصد

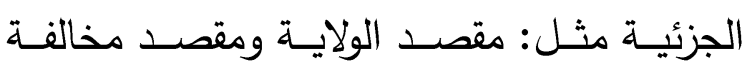
المشركين، ومقصد الجهاد(ع)، وغير ذلك.

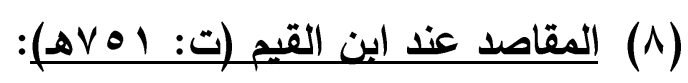
يتجدى اهتمامه بالمقاصد حيث_أضـاف إضـافة جديدة إلى علم المقاصد بإثبات مقاصد الشريعة

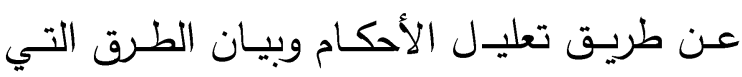
يستفاد منهـا التعليـل وبيـان الحكم، وتوسـع فـى

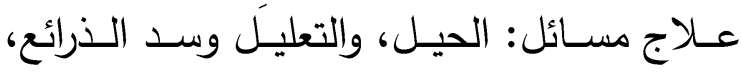
ومسـألة التعليـل وسـد الذرائع ، وأكد على تغيـر

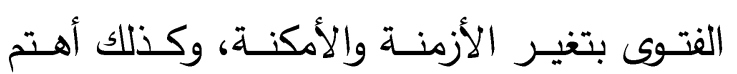
بمقاصد المكلفين ونياتهم(ror).

\section{(9) المقاصد عند الطوفي (توفى 1 V 1 هـ):} يتجلى اهتمامه بالمقاصد حيث كان توسع في

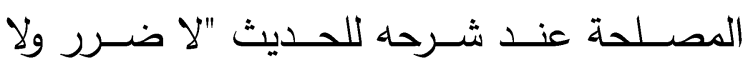

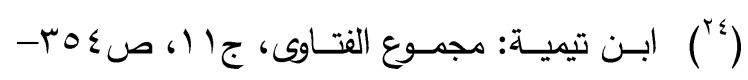
ס ס

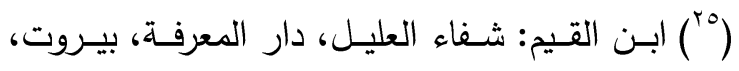

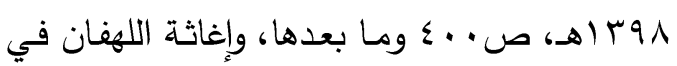

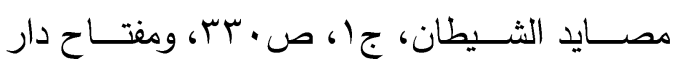

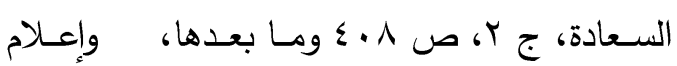
الموقعين، جr، ص. r. 
طـلاب العلـم....، حتى وصـل إلى زمانــا طـور الاسـتهلال، حيـث ظهـر عمـل التطبيـق بتحقيـق الصسور ليصبح اجتهادا جديدا هو الاجتهاد في المسـائل باعتبـار مــداركها أو باعتبـار وفائهــا

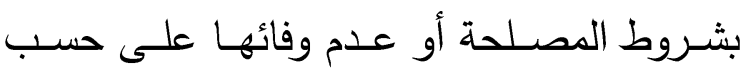
مقتضــيات الأحـوال، وفـى كـل طـور مـن هـــه الأطوار لم يقصر العلماء من الاجتهاد إذا نزلت بهم نازلة، وذا حال المسلمين منذ أن نشأ الدين وإن تخللها جمود عـارض، فتوارث العلمـاء هذه الاجتهادات منذ القرن التاسع الهجري إلى اليوم، بعضهم يشرحها ويفصل مجملها، وبعضهم الآخر يوجزها ويجمل مفصلَها، لذلك أصبح لدينا تركة كبيرة، مستقلة فى كتب المقاصد العامـة للشريعة أو مندرجة في كتب أصول الفقه.

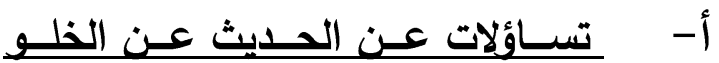

والتوقف التطوي للمقاصد في هذه الفترة: لقد استوقفني كثيرا معنى خلو علم المقاصد من تجديد يذكر خلال قرون خمسة- من الإمـام الثـاطبى(ت: • و Vهـ) إلى الثـيخ الطـاهر بـن عاشـور (ت: بوس اهـ)- فهـل توقـف التــاريخ وتجمـد عندـ هذه النقطـة؟! وكأنها حلقـة مفقودة يتحدث عنها الكثيرون تصريحا أو تلميحا بعصر التخلـف أو التقليــد أو العصــور الوســـى، أو يتجاهله آخرون.

مما جعلني أطرح بعض الترون التساؤلات عن هذا

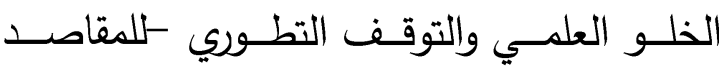
خاصة- الذي يتحدثن عنه، والاجتهاد في وضع بعض الخطوط العربضة للإجابة عنها، ومنها:
قسمين، بالنظر إلى طرفي التشريع وهما: مقاصد الثـارع ومقاصــ المكلف، وقسـم مقاصــ الثـارع إلى أربعة أقسام ما وضعته الثريعة ابتداء وهى

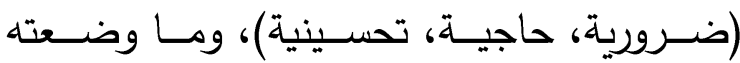
الشـريعة لإفهـام المخـاطبين وهـي تتحصـر في اعتبارين: اللسان العربي، وأمية المجتمع العربي، ومـا وضـعته الشـريعة للتكليف بمقتضــاها وهـى شروط التكليف، والتكليف بالثـاق، ومـا وضـعته الثريعة لاخول المكلف تحت أحكام الثربعة وهى إخراج المكلف عن داعية هواه حيث يكون عبدا الله اختيار كما هو عبد لله اضطرارا، وتوسع في التفريع على المقاصد، وربطها بكثير من المسائل الأصولية (rV)

(Y) الفترة مـا بـين الإمـام الثـاطبي والثـيخ

\section{اين عاشور:}

لقد مضـت حركـة الاجتهـاد في الدين، قويـة سديدة، مطردة وخصبة، يتوالد بعضهها من بعض

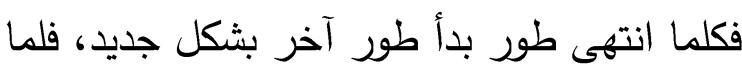
انتهى طور التأصيل على يد مؤسسيه واعتمدوا أصسوله دخل العلم في طور التقريع، وهو طور التقنين بتأليف مختصـرات محـررة على طريقـة الاكتفاء بأقوال ثبتـ، وإن كان على إلزام منهم بهذه الأقوال وضيق نطاق، فكانت هذه المرحلة ضـرورة لهـذا الطـور لتسـهيل إيصـالها لمـدارك

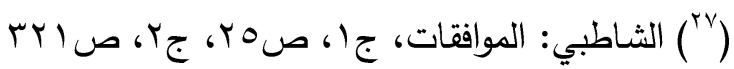
ومـا بعدها، حمادي العبيدي: الثـاطبي ومقاصد

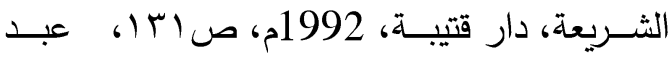
القادر حرز الله: المدخل إلى علم مقاصد الثريعة، داءل، 
r- مـا انتشر من أسـاليب عقيمـة في درس

العلوم وتحصيلها بداية من القرن التاسع: فقد أخذ النـاس يعكفون على "المختصـرات" يحفظونهـا، ويرددون أقوال غيرهم، وتركوا الاجتهاد والبحث

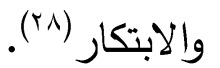

ب- هل كانت حاجة المرحلة أن تتجه اتجاها آخر في التأليف؟ حيـث تظهـر سـمات هـذه المرحلـة في عـدة

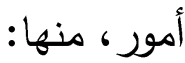
ا- أن الاجتهـاد لا يتوقـف مـادام للإنسـان عقل، فطبيعة الإنسان أنهـ مفكر وإلا كان جمادا، ولكن صور التفكير والاجتهاد مختلفة على حسب مراحل العلوم وتطورها، واحتياج الإنسـان إليها، وظـروف كـل مرحلـة والإمكانـات المتاحسة فيهـا، وخاصــة أن الاجتهـاد فـي الثـريعة الإســلامية معظمه كان قضـاء أو إفتاء منذ خلافة أبى بكر رضـي الله عنـه إلىى أن انتهـى بانتهـاء المحساكم الثرعية عام • AV ام وإنشـاء المحاكم المختلطة في مصـر وغيرهـا مـن الدول الإسـلامية، فانتقل إلى مرحلة أخرى "اجتهاد فقهي"، وهل يتصور أن لا يجتهـد القاضـي أو المفتى إذا نزلت نازلـة؟!؛ يقول الدكتور على جمعة: في حديثه عن الدور الرابـع في التأليف "العصـر الحـيث" وفي هـا الدور الذي يبدأ من سقوط بغداد في القرن السابع

( الثـاطبي: الموافقـات، مقدمـة المحقـق أبـو عبيـدة

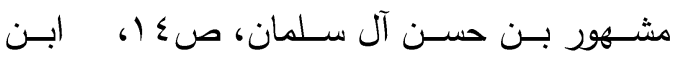

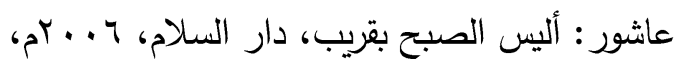

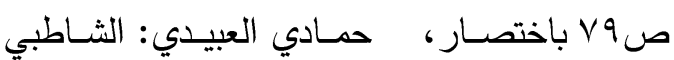
ومقاصد الثربعة، صلV • (1.
أ- - هل كان كتاب الموافقات من الصعوبة بمكان حتى يتأخر الزمـان في فهمــه واسـتيعابه ونشره وتطوبره؟ حيث يرجع خمول ذكر كتاب الموافقات إلى

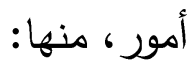

1- المباحـث التـي اشـتمل عليهـا: فهـذه المباحث مبتكرة مستحدثة لم يسبق إليها المؤلف، وجاءت في القرن الثامن بعد أن تم للقسم الآخر

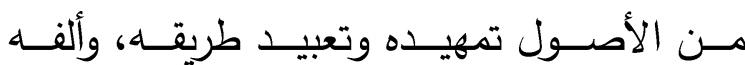
المشتغلون بعلوم الشريعة وتتاولوه بالبحث والشرح والتعلم والتعليم، وصـار في نظرهم هو كل مـا يطلب مـن علم الأصـول، فلم تتطـاول همـة مـن سمع منهم بالكتاب إلى تناوله وإجهاد الفكر في مباحثه، واقتباس فوائده.

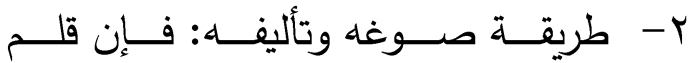
الشـاطبى كرحــهـ الله- وإن كـان يمشــي ســويا ويكتب عربيا نقيا؛ فهناك ترى ذهنا سيالا، وقلما جوالاً، قد تقرأ الصفحة كاملة لا تتعثر في شيء من المفردات ولا أغراض المركبات، إلا أنـه في مـواطن الحاجـة إلى الاسـتـلال بمـوارد الشـريعة

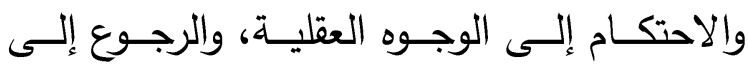
المباحث المقررة في العلوم الأخرى، يجعل القارئ ربمـا ينتقل في الفهم من الكلمـة إلى جارتها، ثم منهـا إلى التي تليها، كأنسه يمشـي على أسـنان المشط، فمـن هذه الناحيـة وجدت الصـوبة في تتاول الكتاب، واحتاج في تيسير معانيـه وبيان كثير مـن مبانيـه إلى إعانـة معانيـه، ومـع هذا، فالكتاب يعين بعضــه على بعض، فتراه يشـرح

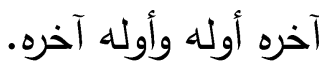


جيل، حتى أتت إلينا غنيـة موفورة تقدم بعض العزاء على ما فقدناه من تراثنا العربي الذي ذهب بـه الغزو التترى، وأتت على كثير منـه الحروب ماء الصليبية، ولم يقف جهد العلماء عند حد دراسـة هذه الكتب وخدمتها، ولكنهم بذلوا جهدا أصيلًا، وأضافوا شروة جديدة إلى شروة الأقدمين"(·r).

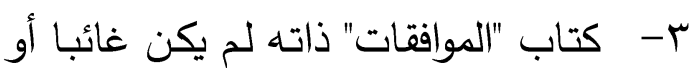
مجهولا - في المغرب العربي- كما قيل فقد كان

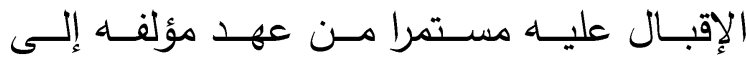
اليوم(')"، وإن تأخر وصوله إلى المشرق العربي في أوائل القـرن الثـاني عشـر الهجـرى/ القـرن

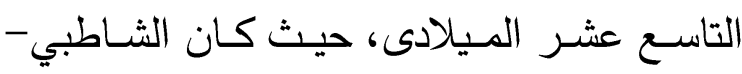
رحمه الله تعالى - من أهل غرناطة الأندلسية كان في المغرب، وكتاب الموافقات نقل من الأندلس بعد سقوط غرناطـة إلى تـونس وطبـع هنـالك ثم انتشر في المشرق حيث "تبه الثيخ تحمد عبده في مطلع هذا القرن طلاب الأزهر وعلماءه إلى كتاب

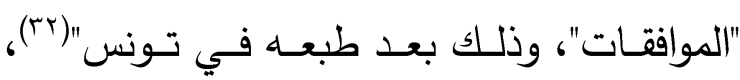
ويؤكد هذا قول الشيخ عبد الله دراز : إنـه كان

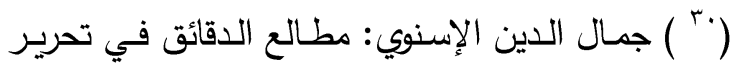

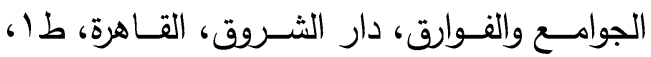

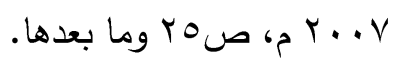

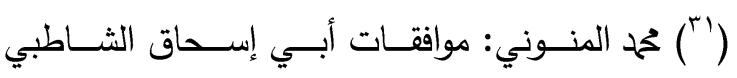

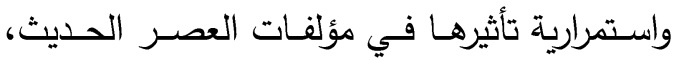

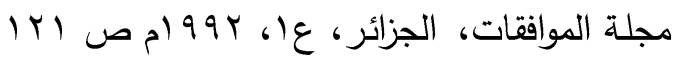

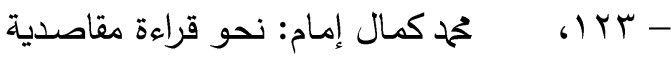

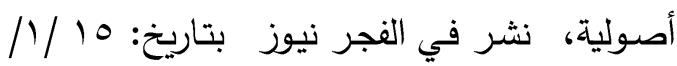
./https://alfajr-news.net ، ( ) الثـاطبي: الموافقـات، مقدمـة المحقـق أبـو عبيدة مشهور بن حسن آل سلمان، جا، صباته
الهجـري، ويمتـد إلى وقتنـا الحاضـر ...، واتجـهـ فقهاء هذا الدور إلى التأليف، وكان الغالب عليه الاختصـار حتـى وصـل إلـى درجـة الإخــلال بالمعنى، وخفاء المقصود، وصسارت العبارات لغزا في هذه المختصرات، والتي احتاجت إلى شروح توضــح معانيهـا، ثـم ظهـرت بجانـب الثـروح: الحواشــي، وهـي تعليقـات، وملاحظــات علـى الشروح، إلا أن التأليف لم يقتصر على ما ذكرنا، فقد وجدت كتب الفتاوى وهي أجوبـة لمـا كان النـاس يسـأل عنـهـ الفقهـاء فـي مسـائل الحيـاة العملية، كما أن هذه الفتاوى غالبا ما يذكر معها ئهاء أدلتها مـن نصـوص المـذهب الذي يتبعـه الفقيـه المفتي، أو تــكر الأدلــة مـن الكتـاب والسـنـة، وغيرهما دون تقيد بأدلة المذهب الواحد"(r9). r- كانـت همــة العلمـاء وهـدفهم الأول في وني هـذه الفتـرة -فــي ظـلـ الحــروب والكــوارثالمحافظـة على التـراث العربـي والإسـلامي مـن الضسياع، ويؤكد على ذلك الدكتور نصـر الدين فريد واصـل في حديثه عن الحركـة العلميـة في عصـر الحـروب الصـليبية- في تحقيقـه لكتـاب

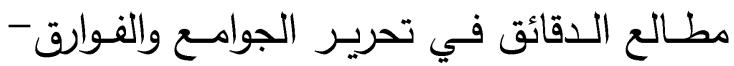

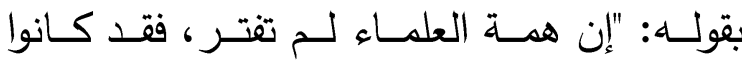
موكولين بتراث العرب وتجميع ما تبقى لديهم من أصــوله، يحفظونــهـ مــن الضــياع ويقونــهـ شـر الخطـوب، وكـوارث الحـروب...، وظلـوا حفاظًا على هذه الثروة الفكريـة يسلمونها مـن جيل إلى ( ) على جمعـة: المدخل إلى دراسـة المذاهب الفقهية،

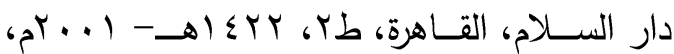

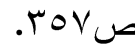


الباب إلى العلماء لاستكمال المسيرة العلمية مما

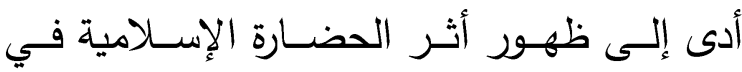
أواخر القرن الثالث عشر الهجري، فقد اهتمـت

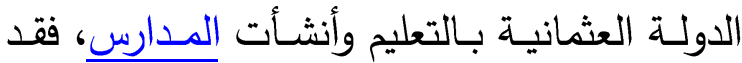
كان السلاطين العثمانيون دائما ما يطورون نظام التعليم ويقدمون الدعم لـه، وقد اهتمـت بتدريس العلوم الدينية والدنيوية وأنشأت الجامعات لتدريس هذه العلـوم، وفتح أبوابهـا للطـلاب القـائمين في العاصمة، والوافدين من مختلف الأقاليم العثمانية، حتى غدت مركزا ثقافيا هاما، وكانت هذه الكليات تدرس مختلف العلوم فإحدى هذه الكليات كانت تدرس العلوم الدينية وعلوم الفضـاء والرباضـيات والهندسة و والاجتماع و والحقوق والآداب والطب،

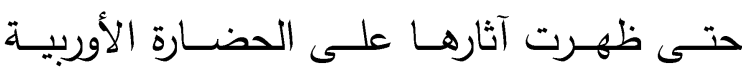
الحديثة)

ب- مـا المواتـع التي أدت إلى عدم ظهور التطور المنهجي في هذه العصور؟

- الحروب العثمانية مع الدول المجاورة: حيث أن كثرة الحروب في هذه العصور على العلم الإسلامي وتكالب الأمم عليها جعل انشغال العلماء عن التأليف النظري إلى التطبيق العملي للدين ومقاصده، ومن هذه الحروب:

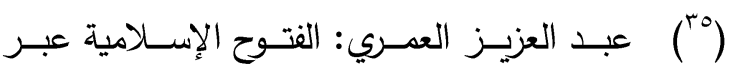

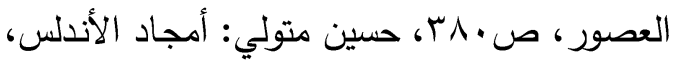

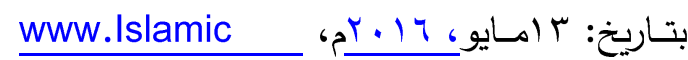
Religion.com ./https://ar.wikipedia.org
حرصا على تنفيذ وصية الإمام محمد عبده، لكنه وفق بعد عسر إلى استعارة نسخة بخط مغربي من بعض الطلبة، ذات خط ملغز ، ثم يسر الله طبعه بمصر فأتيحت لله فرصـة النظر فيه

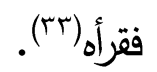
ع- ـ وكـان في المشـرق مـن يكمـل مسـيرة سلفهم في تجديد الدين "فمن المجددين في القرن التاسع الإمـام حمحم بن يوسف السنوسي التلمساني

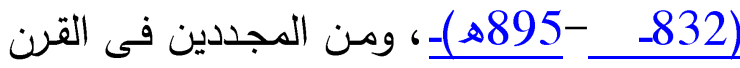

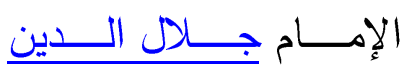
العاشـــر السيوطي(849هـ - 911هـ)، ومن المجددين في القرن الثاني عشر الإمام ولي الله الدهلوي(1114

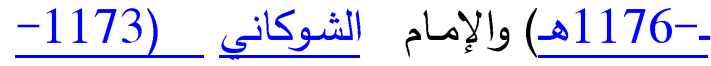
1255هـ) ، والإمـام حسن العطار (1180 -1250هـ)، ومن المجددين في القرن الثاني عشر الإمـام صـديق حسن خـان (1248هـ)؛

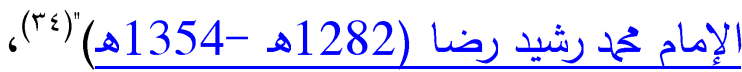
ولا يخلوا الزمان من مجدد، وهؤلاء وغيرهم، عند التدقيق نجد أنهم أضـافوا في العلـوم الإسـلامية أصولها وفروعها ومنها علم المقاصد، مما يحتاج إلى زيادة دراسة وتتبع.

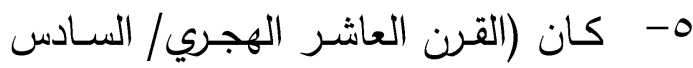
عشر الميلادي) عثمانيَّا خالصـا، حيث استقرت

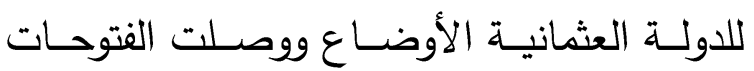
الإسـلامية إلى منتصـف أوربـا تقريبا، ممـا فتح

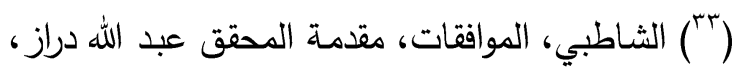

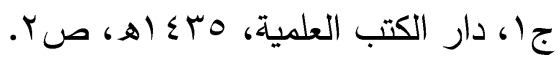

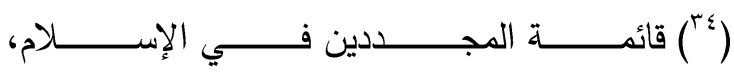
.https://ar.wikipedia.org 
وعلى السـاحة الغربيـة كـان التفـوق الاسـباني والبرتغـالي ملحوظًا، وإن كـان التفوق الهولندي

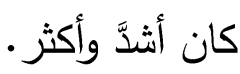
أمـا القرون الثلاثة التالية وهي القرن الثاني عشر والثالث عشر والرابع عشر الهجري (الثامن

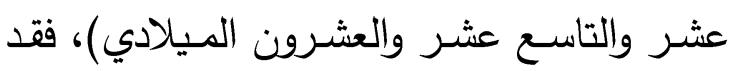

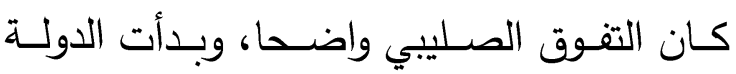

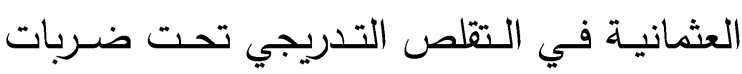

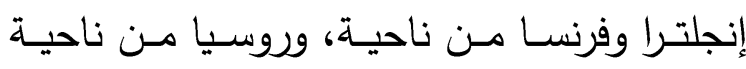

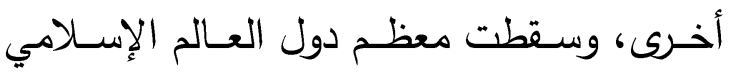
تحـت الاحتلال الإنجليزي والفرنسي والروسي دوسي والصيني والهندي، وكذلك اليهودي الصهيوني في فلسطين بمساعدة الإنجليز •

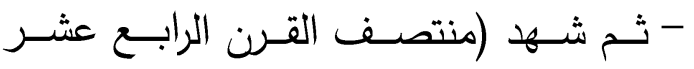
الهجري/ منتصف القرن العشرين) موجة تحرر

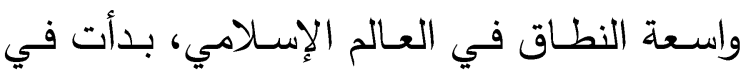

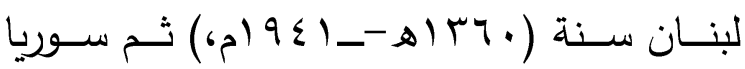

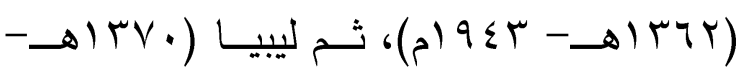

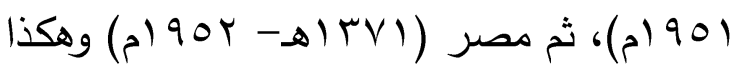
تتابعت الدول الإسلامية في التحرر حتى لم يق التق إلا فلسطين، وسبتة ومليلة في المغرب(r^). ( ) ابـن الكردبـوس: تـاريخ الأندلس، معهد الدراسـات

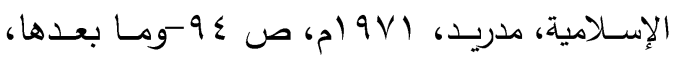

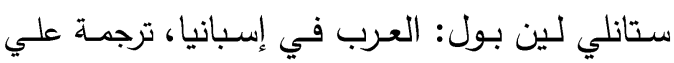

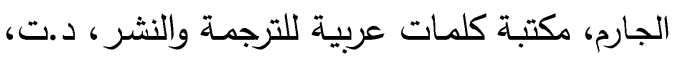

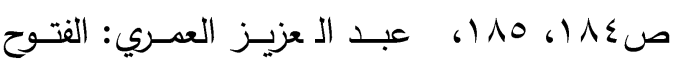
الإسلامية عبر العصور، دار إثبيليا، الرياض، طب، العرئ

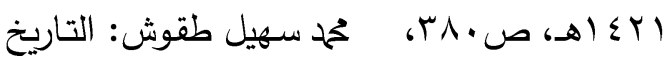

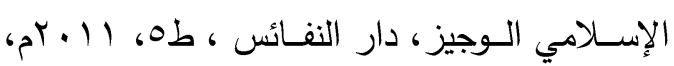

-الحمـلات الصـليبية السـبعة والتــي بــأت الأولى منها سنة ـ9 §هـ، وانتهت السابعة سنة (rT) 1 ( 1 ( 14 - بعد انتهاء الحملات الصليبية السابعة بدأ

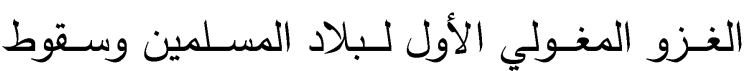

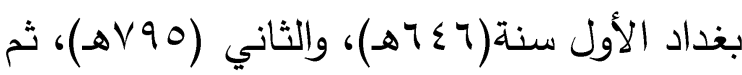

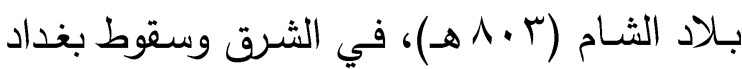

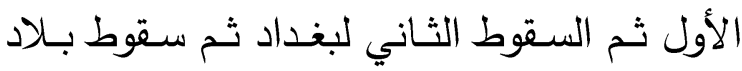
الشام (rv) - محاربـة الدوبـة العثمانيـة مــع الصـفويين

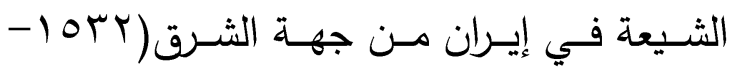
. (م) (م) - سقوط الأندلس ثم سقوط غرناطـة -آخر معاقل المسلمين في الأندلس فى القرن التاسـع الهجري(الخامس عشر الميلادي) وبالتالي خروج

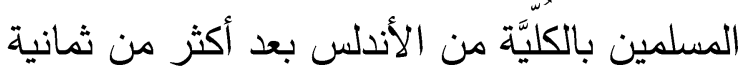

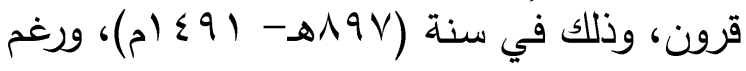

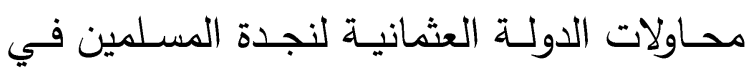
الأندلس إلا أن محاولتهم باءت بالفشل؛ لانشغال

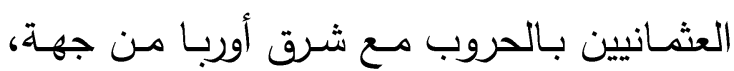
والصفويين الثيعة في إيران من جهة أخرى.

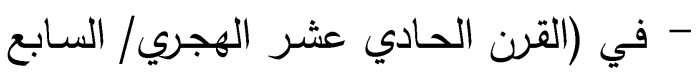
عشر الميلادي) استطاعت بعض الدول الأوربية

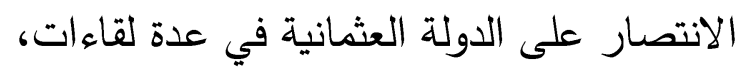

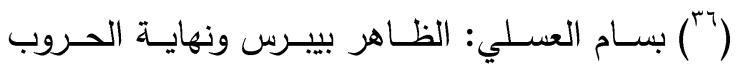

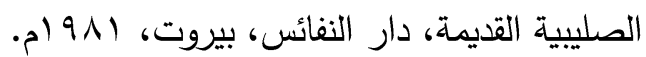

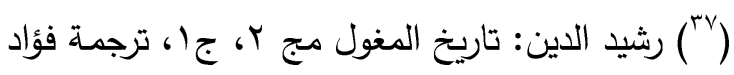

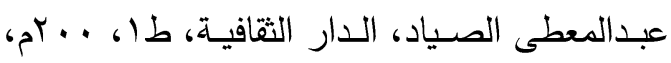
ص ט. 
والتكثيف والفهرسة....، والمقصود هنا هو مناقشة أعمـال المستثـرقين للنظـر في مـدى الاعتمـاد عل يهـا مصــدرا مـن مصــادر المعلومــات في الدراسـات العربيـة والإسـلامية، وهـل تصـل هـذه الأعمــال إلـى درجــة مـن الثقـــة يمكـن معهــا

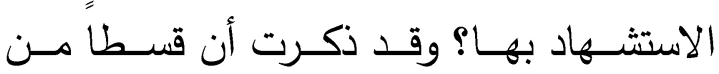
الإسـهامات العربيـة في مجـالات التراث قد بـدا عليها التأثر غير المباشر، وكان لهذا التأثر أثره في الفجوة بين المسلم وثقافته، هذه الفجوة التي حفرها المستشرقون بالغوص في معلومات التاريخ

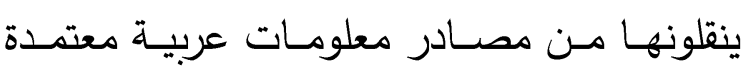
عندنا على أنهـا مـن (أمهـات الكتب) ولكنهم بغوصهح هذا يعتمدون سوء النقل وسوء الاقتباس وسوء الاستشهاد ضـاربين صفحا عن مفهومات علمية كالأمانة والدقة والتجرد والموضوعية، وهم بهذا يلجئون إلى المعلومات الغريبة غير الموثقة في أمهات الكتب العربية فيتكئون عليها، وتراهم يحيلونك إلى المصـادر التي يستشهدون بها أو يقتبسـون منهـا ببياناتهـا الوراقيـة (البيليوجرافيـة) التامةة..."(rq) ت- ومضـات مـن نـور اسـتخرحها العلمـاء من كنوز دفينة وما زالت تحتاج إلى كثير جها لإخراجها:

1- المقاصد عند ابن عاصم الغزنـاطي(ت:

:(A A 9

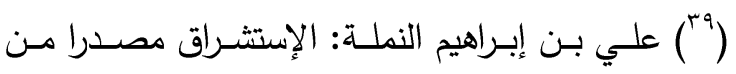

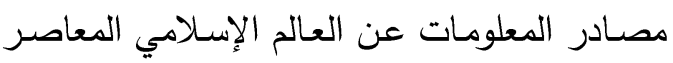

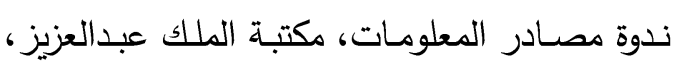

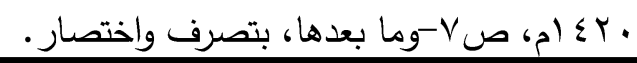

r- كنوزنا العلميـة كانت كومـا يزال الكثير

منها- في أيدي غير المسلمين في هذه القرون وكذلك كانت ترجمتها على أيديهم بعد ذلك: فلقد كان الحديث عن الخلو الفكري والعلمي لهـذه الفتـرة مقصـودا ـــيس مـن قبـل الكتـاب المسلمين - لتعميم مقولة "القرون المظلمة" وكأنها سمة عالمية، وكان للمستشرقين أو غيرهم يد في إخفاء كل ما يتصل بهذه المرحلة -وخاصـة وهى

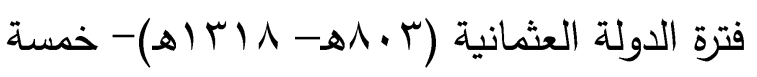
قرون، لإخفاء معالمها في جميع النواحي وخاصة ومعـالم الأحداث الحربيـة التي حصـلت في هذه القـرون، وليحـــث بــذلك الفصــام القــائم فـي الثخصية المسلمة اليوم!، يقول الدكتور علي بن إبراهيم النملـة في كتاب (الاستشراق مصدرا من مصــادر المعلومــات عـن العــالم الإســلامي المعاصـر ): "حيث وصـلت مؤلفـات المستشـرقين في فترة مائة وخمسين سنة ( . . 1 1- . 90 (م) إلى ما يربو على ستين ألفا بين كتاب ومقالة في الفلسفة والتصوف والتاريخ والتراجم وتاريخ الأدب واللغة العربية، ويضاف إلى هذا إصدار أكثر من ون ون خمسمائة ( . .0) دوريـة ذات علاقة بالاستشراق،

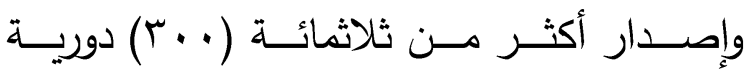

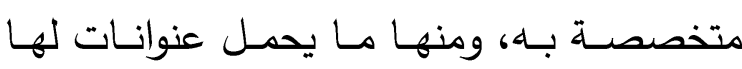
جاذبية للمسلمين أنفسهم. أمـا المعاهد والمراكز التي تهتم بالاستشـراق

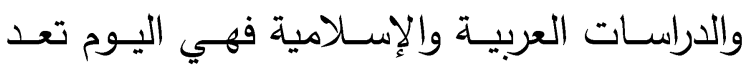
بالمئات في آسيا وأوربا واستراليا وأمريكا، وحيث فشـا الاعتمـاد على إسـهامات المستشـرقين في مجــالات عــدة كالدراســات والتحقيـق والنشــر 


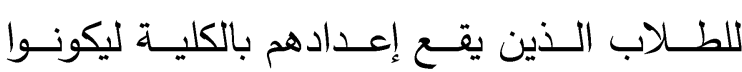
قضاة (\&)

وتـأثر الشـيخ محمد رشـيد رضـا (ت:0با (م)

بكتاب "الموافقات" فأخذ يعالج النواحي المصلحية في الثـريعة، ويـكر أن مسـائل المعـاملات مـن سياسية وقضـائية وغيرهـا ترجـع كلها إلى قواعد حفظ المصـالح ودرء المفاسد، وكل مـا علم من مقاصد الشريعة، ولكن رشيد رضـا لـم يقف عند التأثر بالمقاصــ وإنمـا كان تأثير الثـاطبي فيـه بالغا حده بكتاب "الاعتصام" ورأى أنه لا تتحصر فائدته في كثف البدع واستئصالها فحسب، ولكنه يتضمن أصول الدعوة التي وجه إليها هو جهوده كلها، وكانت أعماله الإصلاحية تتطلق منها(r؟).

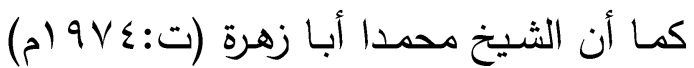
وجه جهوده في مصنفاته الفقهية لإبراز المقاصد

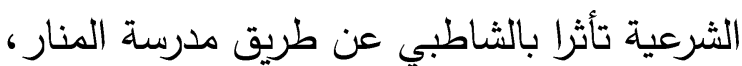

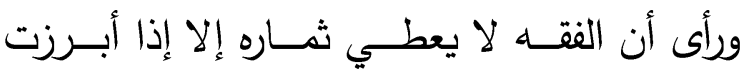

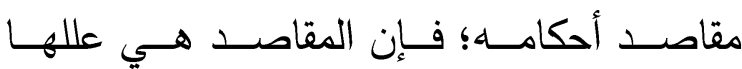
الحقيقية، ويقول هذا الكلام وهو يكتب عن ابن حزم الظـاهري الــي يقوم مذهبـه على رفض التعليل إطلاقا(")؛. ويـــكر الشــيخ محمد الخضـــري البــاجوري (ت:9rV أم) أن ما اهتدى إليه الثـاطبي ألصق بالاجتهاد من أصول الفقه (ءء).

(1) الثاطبي: الموافقات، مقدمة المحقق عبد الله دراز

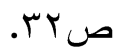

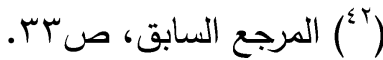

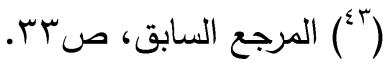

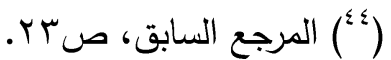

هو أحد تلامذة الشاطبي، وكان اتجاهد اتجاها أخر في عـرض المقاصــ حيـث نسـب -بعض المعاصرين - إليه نظم كتاب "الموافقات"، وسمى ". نظمه "نيل المنى من الموافقات"، وعلى إثر ذلك قام الثيخ ماء العينين بن مامين (ت: · ا9 ام) بنظمـه، وســي منظومتــه "موافق الموافقـات" ثم شـرح المنظومــة وســـي الثـرح "المرافـق على

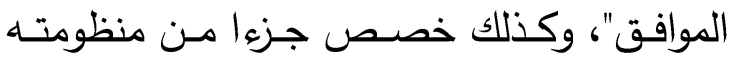

(مرتقي الأصول) لنظم المهم من المقاصد(·ء). r- الأزهر الثريف وعلم المقاصد: الأزهـر الثـريف لـه بـاع طويـلـ في خدمــة المسـلمين وعلـومهم الدينيـة والثقافيـة، ومـن هـذه العلوم علم المقاصد فقد كان كتاب "الموافقات" مـن كتـب الأصــول الـذي يــدرس فـي الأزهـر الشريف، وكذلك احتضن الباحثين لدراسة مباحث علم المقاصد وتطويره، يقول الثيخ عبد الله دراز

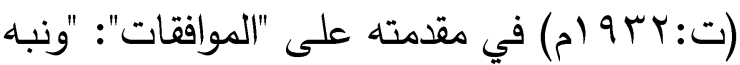
الثـيخ حمد عبده (ت:0 ، 9 (م) في مطلمع هــا القــن طــلاب الأزهــر وعلمــاءه إلــى كتــاب "الموافقـات"، وذلك بعد طبعـه في تونس، وكـان يوصي به الأساتذة والعلماء؛ فيذكر محم الخضري أنـه لمـا كان بالسـودان يــرس علم أصـول الفتـهـ (") محمد سـعد اليـوبي: مقاصــد الثــريعة الإســلامية

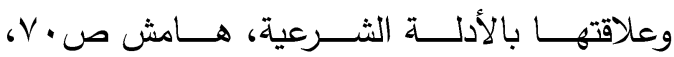
الإسنوي: نهاية السول شرح منهاج الوصول، ج؟، باله

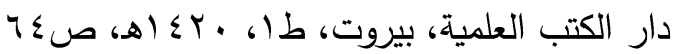

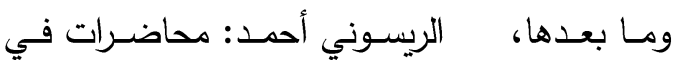

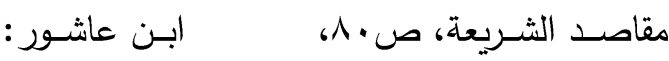
مقاصد الثريعة الإنلامية، صنوف 
ويـذهب عبـد المجيـد تركـي إلـى أن كتـاب

"مقاصد الشريعة" للشيخ حمد الطاهر بن عاشور

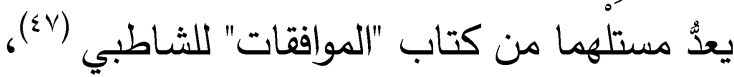
وبالمقارنـة بين الجزء الثاني المخصص للمقاصد من كتاب "الموافقات" للثـاطبي، وكتاب "مقاصد الشـريعة الإسـلامية عند الإمـام حمـ الطـاهر بـن عاشور" تكثف عن أمرين: أولهما يتعلق بالناحية العلميـة، وثانيهمـا بالناحيـة المنهجيـة، فمـا يتعلق بالناحية الأولى؛ فإن ابن عاشور خصص بحوثا خاصــة للمقاصـــ في أبـواب المعــاملات، بينمـا الثاطبي تتاول المقاصد كلها تناولا عاما، وأما ما يتعلق بالناحية الثانية وهي الناحية المنهجية، فإن

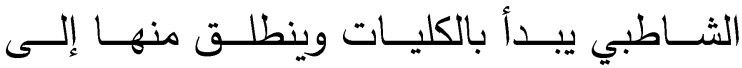
الجزئيـات وبـذلك يـهـج مـنهج الأصـوليين، بينمـا ابـن عاشـور يسـلك عكس هـا المـنهج؛ فيعـالج قواعد المقاصد من منطلق الأمثلة الفرعية، فيسلك بذلك مسلك فقهاء الفروع(^)، وأضـاف نوعا من الن المقاصـــ ســـاه”مقاصــ التشـريع الخاصــة بـأنوع المعاملات"، الذي خصص لـه القسم الثالث من كتابـه، وأدرج تحتهـ من مقاصد خاصـة ببعض الأبواب الفقهية، كمقاصد أحكام العائلة: (النكاح، النسب، المصـاهرة)، ومقاصد التصـرفات المالية، والمقصد مـن العقوبـات، ومقاصـد أحكام القضــاء والثــهادة ، ومقاصـــ الثـريعة فـي المعــاملات

$$
\text { ( })
$$

$$
\text { الإسلامية، ص }
$$

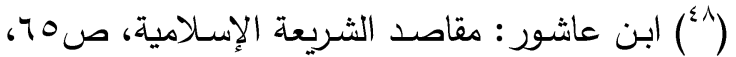
علال الفاسي: مقاصد الثريعة الإسلامية ومكارمها، دار الغرب الاسلامي، طه، بو9 ام، صلهن.
المرحلة الخامسيـة المقاصد فِي القرن

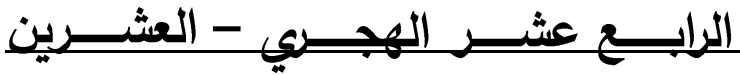

المبلادي -

منـذ بـدايات القـرن العشـرين بـدأت الصـحوة

المقاصدية المعاصرة حيث طبع كتاب الموافقات للثـاطبى أول مـرة في تـونس، و"هذه الطفـرة لـم تتبـت من فراغ، ولم تأت بغتة، بل هي مسبوقة ومعـززة بالحركـة الإصـلاحية التجديديـة الثـاملة التي كانت تعتمد آنذاك لدى علماء مصر وتونس

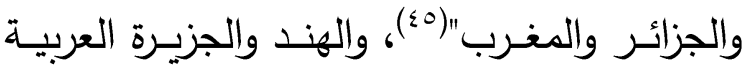
والثـام والعـراق وغيـرهم، وتعـززت كذللك بنشـر كتاب(الموافقات) بعد تحقيقه من قبل الشيخ محهد عبـد الله دراز (ت:90^ ام)، والــي طبـع عـدة

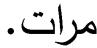

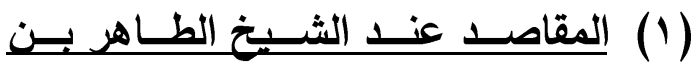

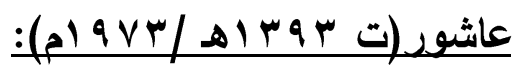
فقــد تـأثر الثـيخ تحمد الطــاهر بـن عاشــور بالثـاطبي في المقاصد، وهو وإن وجها إليه نقدا

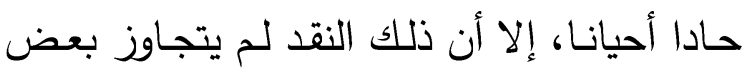
المآخذ المنهجية التي رأى فيها أن الشاطبي اتسع عليـه الموضـوع فوقع في التطويـل والاضـطراب، ولكنـه مـع ذلك لم يستطع إخفاء إعجابه بـه، فنوه بعمله، وأعلن أنه سيقتدي فيه، دون أن ينقل عنـه نقلا حرفيا(Tـ).

(") أحمد الريسوني: البحث في مقاصد الثريعة نشأته وتطوره ومستقبله، مرجع سابق، raissouni.net.

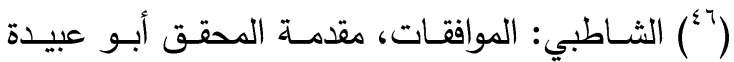
مشهور بن حسن، صعَ 
المرحلة السادسة: المقاصل في العصر الحديث:

دخل علم المقاصد مرحلة جديدة في العصر

الحديث حيث انتشـر في الجامعـات الجامعيـة

والمؤسسات الإسلامية والأدبية، وهذا هو التطور التاريخي الأعظم الذي عرفته مقاصد الثـريعة

والدراسـات المقاصــية منــ كانـت، بـل إن هــا التطور أصبح يخدم مقاصد الثـريعة في سـنة

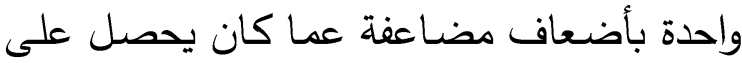

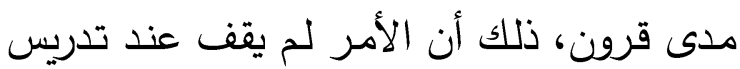
المقاصد لألوف الطلاب في عدد من الجامعات الات عبر العالم، بل امتد إلى البحث العلمي، الجامعي

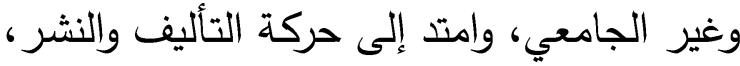
وامتد إلى المجالات والندوات المتخصصـة، ولقد ظهر اتجاهين كبيرين لخدمة علم المقاصد اتجاه

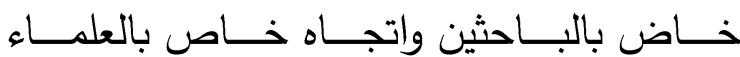
المعاصرين في الاجتهاد في علم المقاصد، وهما على التقسيم التالي: (1) الجاهــات البـاحثين لدراســة علـــ المقاصد:

الاتجــــاه الأول: التـأليف حـول شخصـية الشاطبي وكتابه الموافقات.

الاتجـاه الثالث: دراسـة مباحث المقاصد من الثناسن

غير التقيد بكتاب أو مؤلف، وهي دراسة لا تعتمد دراست مباهن عِلى كتاب أو شخصية لمؤلف بعينها، بل هي لِي

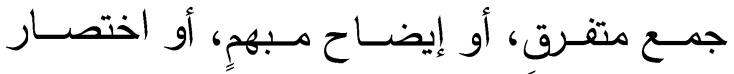

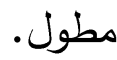
(Y) الاهجاهـات العلمــاء المعاصـرين فـي الاجتهاد في علد المقاصد: ويمكن جعلها في أربعة اتجاهات:
المنعقدة على الأبدان ومقاصد التصرفات المالية،

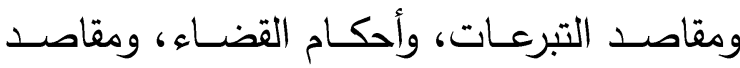
التعجيل بإيصـال الحقوق إلى أصحابها، وأدخل الدراسة المقاصدية في البرنامج الدراسي لجامعة إنسات

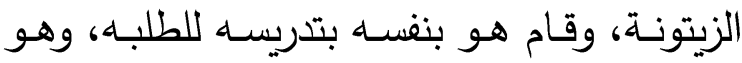

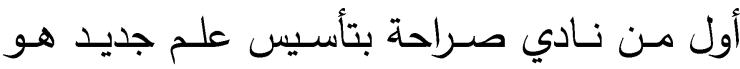

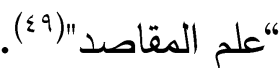

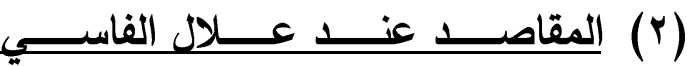

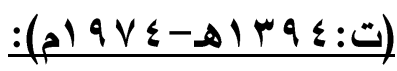

حمل رايـة المقاصـ والفكر الدقاصدي على نطـاق واسـع في عدد مـن المؤسسـات الجامعيـة المغربية، وتوج ذلك بتأليف كتابه(مقاصد الثريعة

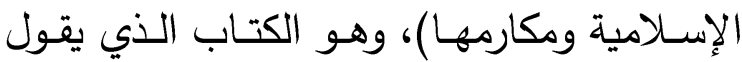

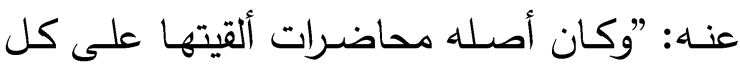
من طلبة الحقوق بجامعة محمد الخامس بالرباط،

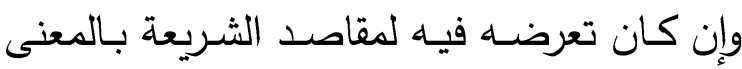
الاصطلاحي قليل، بل غالب ما جاء فيه، الكلام عن محاسن الشريعة مقارنة بالقوانين الغربية،

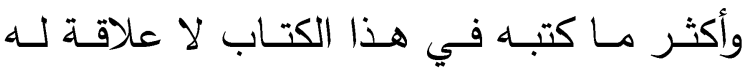
بالمقاصد إذ أكثره ممـا يتعلق بالقوانين الحديثة هدئ والنظم الغربية، وبلا شك أنها يريد أن يبين فضل بـانل الإسـلام على هذه النظم والقوانين، ولكن ذلك لك

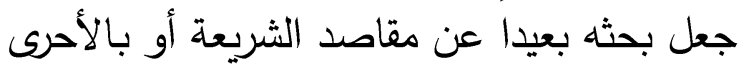

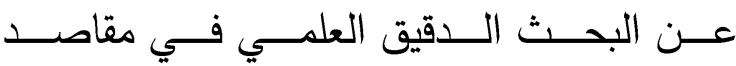
الشربعة (0.). (99 ابن عاشور : مقاصد الثريعة الإسـلامية، ص9$.1 V 7$

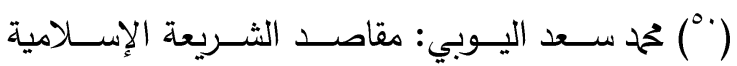

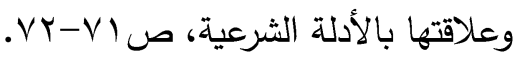


الاتجاه الرابع: يكمن في إعادة النظر في التقسيم جملة وتفصيلا وتجاوز ما جاء قبله، وقد أيد هذا لإنا

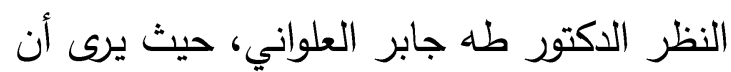
المناهج فى تطور مستمر حسب السقف المعرفي

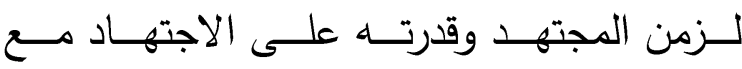
الإلهامات الإلهية النازلة عليه، فقد ذهب إلى أن مقاصــ الثـريعة تتمثل في: التوحيد، والتزكيـة، والعمران، وجعلها المقاصد القرآنية الحاكمة العليا ثم أضـاف إليها مقصدين آخرين وهما مقصدـ الأمـة ومقصد الدعوة، وجعلها المستوى الأعلى إنى

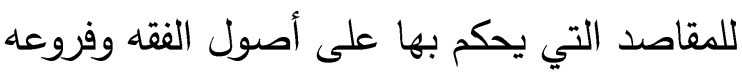

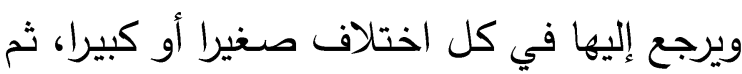
جعل (الكرامة الإنسانية، والعدل) المستوى الثاني للمقاصد والذي يتفرع عن القيم والمقاصد العليا

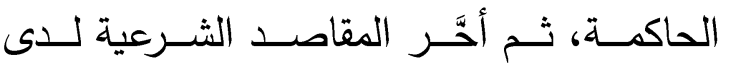
الأصـوليين (الضــروريات والحاجيـة والتحسـينية) إلى المستوي الثالث وسماها بمقاصد المكلفين(و).

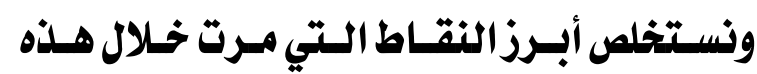

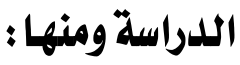

ا.أن أقـرب تعريفـات المقاصـــ هـو تعريـف الدكتور اليوبي: المعاني والحكَم ونحوها،

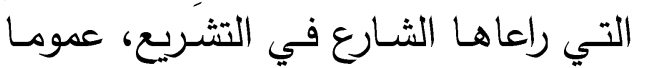
وخصوصـا، مـن أجـل تحقيـق مصـالح

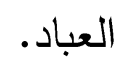

r.أن علم المقاصــ كـأي علم شـرعي كـان موجودا زمن التشريع، وفي عهد الصحابة

( ) ألعواني: التوحيد والتزكية والعمران: محاولات في الكثف عن القيم والمقاصد القرآنية الحاكمة، دار
الاتجــاه الأول: القول بتوسيع دائرة المقاصد

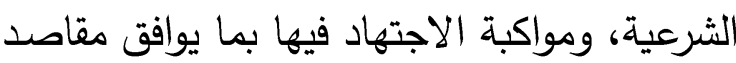

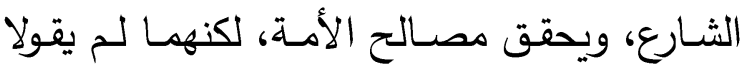
بإعادة النظر في مبدأ الحصر الخماسي للمقاصد

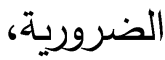
فقد ذهب في هذا الاتجاه: ابن عاشور ، وعلال الفاسي (10). الاتجاه الثاني: اتفق أصحاب هذا الاتجاه على دعوى الزيادة على الضروريات الخمس. لكنهم اختلفوا في نظرتهم إليها، فمنهم من دعا لخاديا

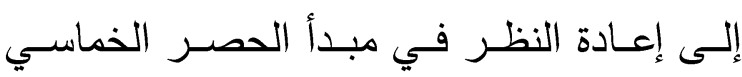
للمقاصد الضرورية، كالأستاذ أحمد الريسوني. ومنهم من سجل ما ظهر لـه من اعتراضـات على هذا المبدأ ومراجعة ذلك المبدأ من أصله،

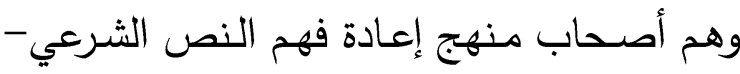

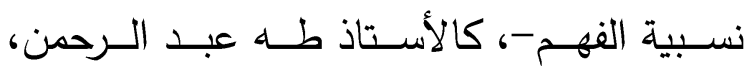
والأستاذ جمال الدين عطية(or). الاتجاه الثالث: يكمن في محاولة إعادة النظر في لإني

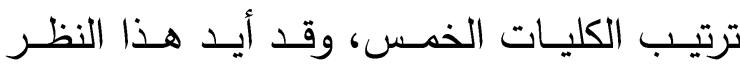

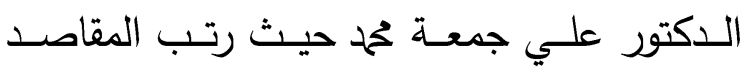

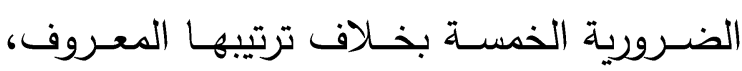

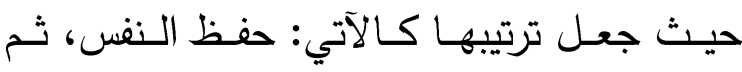
العقل، ثم الدين، ثم النسل، ثم المال (هror.

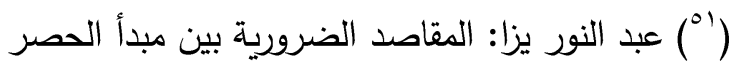

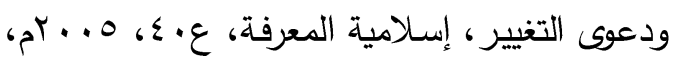

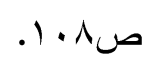

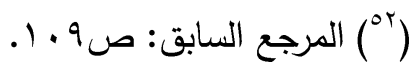

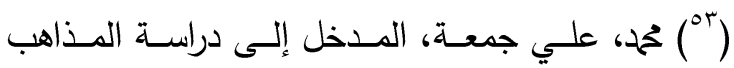
الفقهية، مرجع سابق، صله الس. 
ه.الأزهر الثريف لـه بـاع طويل في خدمـة

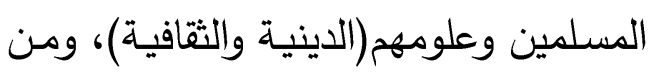

هذه العلوم علم المقاصد فقد كان كتاب

"الموافقات" من كتب الأصول الذي يدرس علد فئد

في الأزهـر ، وكـذلك احتضـن البـاحثين لدراسة مباحث علم المقاصد وتطويره.

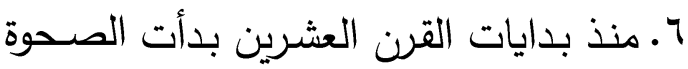

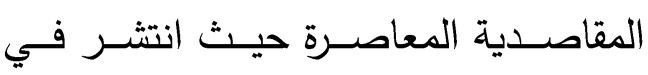

الجامعات الجامعية والمؤسسات الإسلامية

والأدبية، حتى أصبح يخدم مقاصد الثريعة

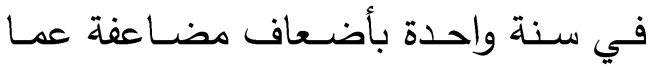
كان يحصل على مدى قرون.

الدعوى لاستقلال علم الدقاصد قد تؤدي إلى لى

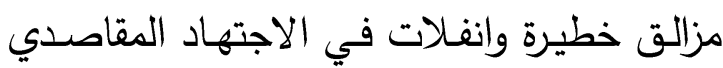

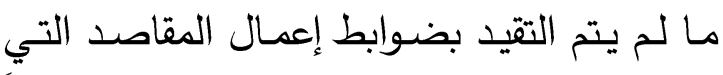
حددها العلماء، حيث أن المقاصد ليست دليلا مستقلاً بل ترابط ارتباطا كبيرا بعلم أصول الفقه لهنه فهناك تداخل في بعض الجزئيات، وهناك تمايز

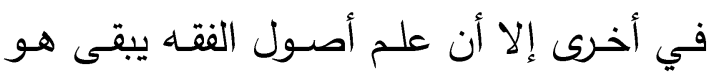
أصل علم المقاصد الآن

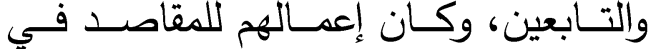
الاجتهاد واضحا وإن لم ينصوا على ذلك، ولقـد مـر علـم المقاصد بـأطوار ومراحل لــل متعـدة حتى وصـل إلـى مـا وصـل إليـهـ الآن، ومن أبرز مراحله قبل تدوينه تميزه في المؤلفات الأصولية.

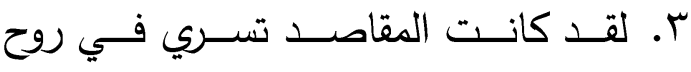
الصحابة وعقولهم، اكتسبوها من النصوص لهاهي

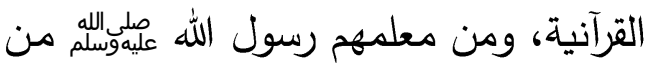
أقوالـهـ وأفعالـهـ وتقريراتـه، فأكسـبهـ ملكـة

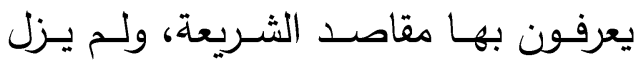

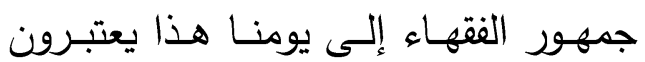
المقاصد في أحكامهم وفي فتاويهم. ع. الفترة ما بين الإمام الثشاطبي والثيخ ابن وفئ عاشـور تحتـاج إلى عنايـة بحث ودراسـة حيث عدمت الدراسات التي تتحدث عنها،

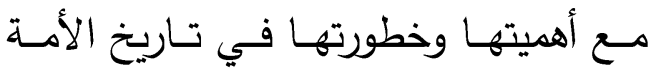

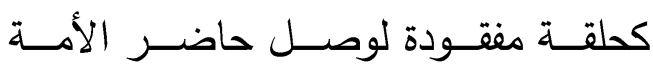
بماضيها وتراثها. 